\title{
Politeness in Anggoro Ihank's "Pak Guru Inyong" Comic
}

\author{
Ni Putu Venia Marelda Artha*, I Nyoman Muliana and Ni Wayan Kasni \\ Program of Master in Linguistics, Universitas Warmadewa, Denpasar-Bali, Indonesia
}

jolenelavenia@gmail.com

\begin{tabular}{|c|c|c|}
\hline Received: $13 / 04 / 2019$ & Revised: 26/09/2019 & Published: 15/10/2019 \\
\hline How to cite (in APA s & & \\
\hline
\end{tabular}

\begin{abstract}
This research aims to explore the accomplishment of politeness principles and the violation on the politeness principles in "Pak Guru Inyong" comic. This research was carried out using qualitative type of research. The data were collected by reading and taking notes from a 40 episode of the comic texts written by Anggoro Ihank and uploded in a Webstoon Aplication. The application was reached in Line application via android. The data were analyzed by using the theory of general strategy of politeness by Leech. The results of the analysis show that there are ten general strategies of politeness accomplished by the characters in the comic: generosity maxim, tact maxim, approbation maxim, and modesty maxim, obligation $\mathrm{S}$ to $\mathrm{O}$ maxim, obligation $\mathrm{O}$ to $\mathrm{S}$ maxim, agreement maxim, opinion maxim, sympathy maxim and feeling reticence maxim. There are five maxims violated by Pak Inyong, such as the maxims of generosity, approbation, modesty, agreement, feeling reticence.
\end{abstract}

Keywords: Comic; maxim; politeness

\section{INTRODUCTION}

Studies on politeness principles and their realization of accomplishments had been undertaken not only by theorists or linguists but also scholars throughtout the world and in decades. Various forms of communication, both in written and in oral forms, had been investigated to see how different contexts, setting, participants of communication, as well as different topics of interaction comply with the politeness principles and their general accomplishing strategies across cultures and nations. The media like films, movies, novels, comics, radios or direct conversation had been the forms of communication frequently taken as the subjects of the studies.

Conceptually politeness has been agreed upon as a form of communication and behavior that is very commonly used by humans to provide benefits or values not for themselves but for others (Leech, 2014). Politeness is an important matter to learn. Acting in accordance with acceptable and valuable ways to the social environment shows respect, care ,and attention to others (Post, 1922). When communicating, there are 10 principles of politeness that need necessarily to be undertaken by the participants in order to allow every communicaion to run well and in accordance with applicable politeness norms in the community. The principles of politeness conceptualized in general politeness strategies can help everyone to act based upon a conventinalised rules, and for the purpose of the present study they provide guidelines to examine the situation of participants's acts of speech involved in a communication activities, like in the comic entitled "Pak Inyong".

Politeness serves as an acute aspect that needs to be considered in translation for it is closely related to culture. Translation does not only handle language but also deals too much with the culture of both the source and the target language. Thus a translator must not put aside the norms of politeness in order to make 
the translation acceptable to the target readers (Nurlaila, et al., 2011). Conversely, the forms of violation of the principles of politeness in the Crayon Shinchan comic had a function to mock, ask, complain, give opinions, rule, declare and boast (Fransischa, 2012). Violations on the principles of politeness and conversational implicature made the Mantab program, a rare comedy talk, show that it became more interesting, more alive, and more impressive (Alfia, et al., 2014).

Leech (2014) classifies politeness principles into ten maxims contained in general politeness strategies, as follows: 1) generosity maxim, must give high value for others, 2) tact maxim, must give low value for speaker, 3) approbation maxim, must give high value to quality of others, 4) modesty, must give low value to quality of speaker, 5) obligation $\mathrm{S}$ to $\mathrm{O}$ maxim, give high value to speaker's obligation for others, 6) obligation $\mathrm{O}$ to $\mathrm{S}$, give low value to other's obligation to the speaker, 7) agreement maxim, give high value to other people's opinions, 8) opinion reticence maxim, give low value to the speaker, 9) sympathy maxim, give high value to other people's feelings, 10) feeling reticence maxim, give low value to speaker's feeling.

One of the factors of the violation on the principles of politeness is the developed technology in this era. The world community easily accesses information and entertainment through internet media. Parents who do not supervise their children can have a negative impact because children and adolescents are quickly affected by the spectacles or readings on the internet. One of the most often accessed entertainment on the internet is comics. Comic is images of characters who speak and produce deep experiences for their readers (Qiang \& Kahn, 2015). Stories in comics are designed in unique ways and bright images that attract readers. Comics with weird pictures and simple main characters proved to attract many readers on the internet. The comic in question is the one entitled "Pak Guru Inyong". The comic has honorary teacher as the main character. It is is a slice of life comic written by Indonesian author, which means that this comic is a reflection of communication that occurs in the social life of Indonesian society. In this comic, the main character is the so-called Pak Inyong, acting as a teacher. A teacher usually has highly noble and virtuous character. A teacher has duties and obligations, not only in educating the students but also in playing a role of model for them.
In the context of Indonesia, a number of related studies had undergone the conduction with different purposes. Nurjannah (2014) has researched perlocution from violations of the principle of politeness in the drama "Kimi $\mathrm{Wa}$ Petto". Karim (2018) has revealed the principles of cooperation and the principle of politeness in the utterances of guests's complaints of hotel X in Kuta-Bali. Budiarta and Rajistha (2018) have disclosed the principles of politeness and violations undertaken by the characters in an animation movie of Adit dan Sopo Jarwo. Doko (2017) have researched language politeness in a collection of folktales of East Nusa Tenggara. Seeing the problems faced in each study above, the politeness principle in fact can be placed as an important thing either in a real life as the analysis conducted by Karim or unreal life as the analysis of Nurjannah and etc. to made people act in accordance with acceptable and valuable ways to the social environment, therefore is interesting to conduct this present study to provide an appropriate act in educational environment.

This study aims to provide guidance on how to communicate politely so that the relationship between speakers and opponents of speech is well-established and in accordance with the conventionaly applicable norms of politeness in each society.

\section{METHODS}

This study makes of qualitative type of research. The data are the written text collected from a 40 episode of "Pak Guru Inyong". The comic are accessed online through the Webtoon online application at www.webtoons.com. The data are collected by reading the texts in each of determined episode and taking notes. The first step is to determine the episodes, the second is to read the episodes that have been selected, the third step is to take notes from the important utterances, namely those identified to involve politeness accomplishment and violation, and the last is to group the data based on politeness and impoliteness, according to the general strategy of politeness by Leech. Lastly, the results of analysis are presented formally and informally. Informal presentation method is the formulation with words ordinary, despite using technical terminology; while formal presentation is the formulation with signs and symbols (Sudaryanto, 2015).

\section{III.RESULTS AND DISCUSSION}


The author of "Pak Guru Inyong" comic is an Indonesian so the story splited out in it is a reflection of the culture, social life, and traditions of Indonesian. The researcher examined episodes 1-40 to determine the character of Pak Inyong which may be this character who have noble character and obey the norms of politeness or only behave politely while working as a teacher. From the episodes $1-40$, it it was found that Pak Inyong's acts of speech accomplish 10 maxims of politeness, that are: generosity, tact, approbation, modesty, and obligation to $\mathrm{O}$, obligation to $\mathrm{S}$, agreement, opinion reticence, sympathy and feeling reticence. Pak inyong's acts of speech also violate 5 norms of politeness reflecting in the form of maxims of generosity, approbation, modesty, agreement, and feeling reticence.

To clarify the results of Pak Inyong's speech acts that accomplish the principle of politeness and violate the principles of politeness, both the table 1 and tabel 2 present the frequency of accomplishment and violation conditions.

Table 1.

Politeness Norms Accomplishment

\begin{tabular}{cccc}
\hline No & Types of Norm of Politeness & Number & Frequency \\
\hline 1 & Generosity & 15 & $25.90 \%$ \\
2 & Tact & 3 & $5.19 \%$ \\
3 & Approbation & 9 & $15.59 \%$ \\
4 & Modesty & 4 & $6.90 \%$ \\
5 & Obligation S to O & 7 & $12,09 \%$ \\
6 & Obligation O to S & 3 & $5,19 \%$ \\
7 & Agreement & 11 & $18,99 \%$ \\
8 & Opinion reticence & 2 & $3,49 \%$ \\
9 & Sympathy & 1 & $1,90 \%$ \\
10 & Feeling reticence & 1 & $1,90 \%$ \\
& Total & 58 & $97,14 \%$ \\
\hline
\end{tabular}

Table 2.

Politeness Norms Violation

\begin{tabular}{cccc}
\hline No & Types of Norm of Politeness & Number & Frequency \\
\hline 1 & Generosity & 2 & $14,29 \%$ \\
2 & Approbation & 2 & $14,29 \%$ \\
3 & Modesty & 1 & $7,14 \%$ \\
4 & Agreement & 5 & $35,71 \%$ \\
5 & Feeling reticence & 4 & $28,57 \%$ \\
& Total & 14 & $100 \%$ \\
\hline
\end{tabular}

As shown in the tables 1, Pak Inyong's speech acts accomplish 10 maxims on the principles of politeness in general strategies of politeness. Generosity is the maxim that is most frequently accomplished because the character likes helping others and even sacrifices for others. The second highest number of frequency is agreement maxim because the character indicating that the character always approves other people's invitations or opinions as long as the invitation or opinion is positive. The third highest number of frequencies of politeness norms accomplishment is approbation maxim. This indicates that the character respects the abilities and physicality of others.

Conversely, Pak Inyong also breaks the rules of politeness as shown in table 2 . Totally the number of violated rules of the politeness is 5 maxims. Agreement is the maxim that is most 
often violated, which indicates that the character often disputes the opinions of others which are negative by giving positive opinions with the aim that others do not have a sense of discouragement and build a feeling of confidence for others. The second is reticence maxim. This happened because the character is an honest sort and could not hide the joy or sadness he is experiencing. Violations on this rule of politeness occur a lot when the character talks with friends and other characters who have higher positions than him. The third. The third highest frequency of politeness norm violated the character is maxim of generosity and maxim of approbation. This happens because the character sometimes gives assignments or repetitions to students by testing the spontaneously, while violations on approbation maxim are led because approbation does not directly give punishments on his students but using expressive functions more often for insinuating with the aim of making the students embarrassed and not repeating the same mistakes.

The character accomplishes the maxim of generosity if he/she gives a high value to the desires of others. The context from data 1 is when Pak Inyong stopped the quarrels between Sunarto and Sastro. Pak Inyong gave them a balanced punishment, spending double-fried noodles school legends.

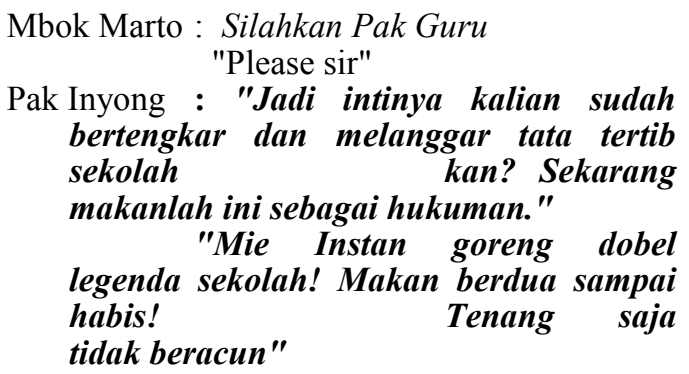

"So basically you guys have quarreled and violated school rules right? Now eat this as a punishment."

"Double fried noodles school legend! Eat together until it's finished! Just calm down nontoxic"

Sastro and Sunarto:

Conversation in 1) took place in the school canteen. In 1), Pak Inyong accomplishes generosity maxim because the character gave benefit for Sastro and Sunarto by giving them food and making them make up. The character who is a teacher should have given a punishment in the form of a burden for Sastro and Sunarto but he gave a punishment in the form of profit to his students. The purpose of the punishment is to make his students understand that inequality will always exist and everyone must tolerate others. Pak Inyong as used generosity maxim in his speech by not harming others and giving benefits to others.

The function of speech acts of Pak Inyong is directive and assertive. The directive speech is seen in the use of command sentence "Now eat this as a punishment!" and assertive speech by convincing others "just calm down non-toxic".

The speakers accomplish tact maxim if they give a low value to their own desires. Data 2 is the accomplishment of tact maxim. This conversation occurred between $\mathrm{Bu}$ Munah and Pak Inyong. It took place in the teacher's office. $\mathrm{Bu}$ Munah asked Pak Inyong for help in teaching scout extracurricular because the teacher members were lacking. That reason was only a fake reason, because actually $\mathrm{Bu}$ Munah just didn't want to bother herself

Bu Munah: Begini pak...kalau tiap jum'at pak Inyong bantu eksul pramuka kira-kira bisa tidak ya? Soalnya kita kekurangan orang.

"Like this sir...if every frieday Pak Inyong helping us to teach extraxurricular scout, do you mind or not? We lack of helper"

pak Inyong: Bisa bu bisa...kebetulan saya kosong kalau hari jum'at

"I don't mind miss... incidentally ... I have empty teaching hours on friday"

$\mathrm{Bu}$ Munah: Benarkah? Kalau begitu untuk detailnya saya hubungi lagi nanti ya? you later

"Really? If so for the details, I'll contact

pak Inyong: $Y$ a bu siap

"Ok miss"

(Eps.5-Senior)

In 2) Pak Inyong said that he could help $\mathrm{Bu}$ Munah to teach scout extracurricular and he is free every Friday. Pak Inyong's speech accomplishes the tact maxim because he puts a burden on himself. He does not choose to relax on his free time. He is willing to help $\mathrm{Bu}$ Munah and not ask for a reward for himself.

The function of the speech act spoken by Pak Inyong is an assertive function because Pak Inyong stated that he was able to help $\mathrm{Bu}$ Munah.

The speakers accomplish approbation maxim if they give praise to others as a form of 
appreciation. Data 3) shows the accomplishment of approbation maxim which was told by Pak Inyong. The situation when Pak Inyong entered Siti's room and Siti kicked Pak Inyong while saying rudely words but Pak Inyong replied to Siti's words by giving her sister a compliment.

Siti: Dasar pengacau!!! Jangan masuk kamar Siti sembarangan!!!"

"You are troublemaker!!! Do not enter Siti's room carelessly"

\section{Pak Inyong: Wah wah adikku yang cantik sekarang tambah tinggi ya? Tendanganya juga makin kuat. \\ "Wow wow my beautiful sister is getting taller now? Her kick is also getting stronger..."}

\section{(Ep.30-Asian Pop Culture)}

Pak Inyong accomplishes the approbation maxim because he did not reply Siti's words who was angry. He replied to Siti's rude words with words of praise. Even though Siti was angry, when she heard Pak Inyong's words, it made Siti happy. Giving praise to others is a polite speech because the form of respecting others.

The speech function spoken by Pak Inyong is a function of expressive because he gives praise with words of praise, such as: beautiful, higher height and stronger kick.

The speaker accomplish modesty maxim if they give low value for their own quality by saying words that humble theirself. Data 4) is the speech of Pak Inyong who accomplishes modesty maxim. The situation occurred when Pak Inyong applied to become an honorary teacher in SMP no 1 Gumiwang Tercinta. He was interviewed about the issue of low salary and Pak Inyong's answer was very low selfesteem.

Kepala sekolah: Jadi anda mau jadi guru honorer di sini ya?"

"So you want to work as an honorary teacher here?"

Pak Inyong: Benar sekali pak

"Absolutely yes sir"

Kepala sekolah:: Tapi gaji per jam pelajarannya tidak banyak lho?

"But the salary per-lesson is not much"

Pak Inyong

Tidak masalah yang penting saya tidak terlihat seperti penggangguran lagi pak

"Not a big problem sir, as long as i dont look like an unemployed man sir"

\section{(Ep.2-Wawancara)}

The speech uttered by Pak Inyong accomplishes modesty maxim because he humbles himself which shows the person who is sincere and humble. Pak Inyong did not mind if the salary a little as long as he got a job. The humble attitude of Pak Inyong made headmaster accepted him to work as an honorary teacher at SMP 1 Gumiwang Tercinta.

The speech function of the speech act uttered by Pak Inyong is an assertive because in the speech there is a clause which acknowledges that "as long as I don't look like an unemployed man".

Obligation $\mathrm{S}$ to $\mathrm{O}$ maxim, the speakers give high value to the obligation of speakers for others. Using apologies and thank you for appreciating the sincerity and effort of others. Obligation to $\mathrm{O}$ maxim in data 5) was told by Pak Inyong. This conversation happened when Pak Inyong's motorcycle broke down and $\mathrm{Bu}$ Idun gave help for a ride so Pak Inyong could arrive at school on time.

Pak Inyong: Akhirnya sampai juga terima kasih bu Idun

"Finally arrived, thank you, Bu Idun"

Bu Idun: Sama-sama...lain kali kalau mogok lagi kirim pesan ke line saya saja ya?

"You're welcome ... next time if strike again just send a message to my line?"

Pak Inyong: Iya bu...

"Yes miss..."

(Ep.7-Doa)

The speech uttered by Pak Inyong accomplishes obligation $\mathrm{S}$ to $\mathrm{O}$ maxim because Pak Inyong as a speaker appreciates the assitance provided by others by expressing gratitude. Pak Inyong expresses his gratitudes to $\mathrm{Bu}$ Idun because she had helped him by giving a ride to school.

The function of the speech act uttered by Pak Inyong is an expressive because in Pak Inyong's speech, he expressing his gratitude "thank you" to bu Idun.

Obligation $\mathrm{O}$ to $\mathrm{S}$ maxim give low value 
to the obligation $\mathrm{O}$ to $\mathrm{S}$. Apology from others is often minimized by the speaker as a form of accomplishment of the principle of politeness. For example: no problem, nothing, or don't worry. Gratitude responses are also often minimized by answering your welcome, no problem, or don't mention it. In data 6) the speech of Pak Inyong accomplishes the obligation $\mathrm{O}$ to $\mathrm{S}$ maxim. This conversation happened in the afternoon when Mas Gopeng came to Pak Inyong's house to ask for help from Pak Inyong to borrow some money.

Pak Inyong: Saya cuma ada seratus ribu nggak apa-apa mas?

"I only have one hundred thousand, is it ok?"

Mas Gopeng: Makasih ya...Ini sudah lebih dari cukup kok. Bulan depan aku ganti

"Thank you...This is more than enough. I'll give it back next month"

Pak Inyong: Santai saja mas

"Relax bro"

(Ep.40-Pahit)

Pak Inyong's utterance accomplishes the obligation of $\mathrm{O}$ to $\mathrm{S}$ maxim. The speech accomplishes $\mathrm{O}$ to $\mathrm{S}$ maxim obligation because the speaker minimizes Mas Gopeng's gratitude by saying "relax bro", which means it does not matter to him to lend money to Mas Gopeng.

The speech function of the speech uttered by Pak Inyong is an assertive by stating "relax".

Agreement maxim occurs when a speaker gives high value to others opinion. The maxim is accomplished if the speaker and hearer have an agreement. Pak Inyong helped $\mathrm{Bu}$ Dwi to make a budget format for the regional students' sports week, because of finishing $\mathrm{Bu}$ Dwi's assignment overtime, $\mathrm{Mr}$. Inyong returned home without telling Bu Dwi. It turns out that $\mathrm{Bu}$ Dwi returned to school and called Mr. Inyong to tell him that she had bought a packet of rice for Pak Inyong. Because Mr. Inyong was at home, Mrs. Dwi asked for Mr. Inyong's response if the rice was given to the school guards

\section{Pak Inyong : Halo bu?}

"Hallo miss?"

Bu Dwi: Pak Inyong kemana? Sudah saya belikan nasi rendang sama es teh tho?

"Mr. Inyong where are you? I bought rendang rice and iced tea" di rumah

Pak Inyong: Waduh maaf bu saya sudah

"Ouch sorry miss, Im home already"

Bu Dwi: Ya sudah jatah makan Pak Inyong saya kasih ke penjaga sekolah saja ya?

"Ok then I will give Pak Inyong's food to the school guard"

Pak Inyong: $\mathbf{Y a}$ bu boleh sayang kan daripada nggak ada yang makan food"

"Ok miss, better than no one eat the

\section{(EP.26-Ujian dan Kemesraan)}

Pak Inyong's utterance accomplishes the agreement maxim because the speaker had an agreement with the opinion expressed by Mrs. Dwi. Bu Dwi said that it is better for the rice to be given to the school guards, Pak Inyong agreed with Bu Dwi's opinion.

The function of speech acts in Pak Inyong's utterances is the directive, namely expressing the agreement indicated by the word "yes".

Opinion Reticence gives a low value to the opinion of the speaker. Speakers often give low scores with their own opinions. Usually their opinions begin with words, such as: $I$ think, in my opinion, might be better, and else that give low tolerance to the speaker's opinions. In data 8), it is the accomplishment of reticence maxim spoken by Pak Inyong when giving advice to his students about monkey love, after hearing Supri presenting his painting explaining that Supri and Shanti's love were like water and oil that he painted

Pak Inyong: Mungkin karena sekarang monyetnya sudah banyak yang berevolusi jadi tidak

heran anak seusia kalian sudah pacaran, tapi ketahuilah. Menurut

pengamatan pak Inyong, hanya 1\% dari mereka yang mampu bertahan

sampai ke pelaminan kebanyakan putus lalu menyisakan puing-puing

\section{kebencian.}

"Maybe because now many monkeys have evolved so it's no wonder children your age are dating, but know. According to Pak Inyong's observation, only $1 \%$ of those who 
were able to survive to the most altar broke up and left behind hate debris"

\section{(Ep.33-Belajar)}

Pak Inyong's speech accomplishes the maximal opinion reticence maxim because the speaker gave a low value to his own opinion. Even though he is a teacher, he still expresses his opinion by accomplishing the opinion reticence maxim seen in the use of words according to Mr. Inyong's observation. This proves that Pak Inyong respects the other opinions of his students.

The speech function spoken by Pak Inyong is a directive in the form of giving advice.

Sympathy maxim, give high value to other people's feelings. Accomplishment of sympathy maxim occurs when the speaker shows others that they can share their feelings. Congratulate when other people reach their dreams, express their condolences when someone dies. Data 9) is an accomplishment of the sympathy maxim, which occurred when Pak Inyong just got his salary and Mamake asked his son to buy her a rice cooker.

Pak Inyong: Mamake...Harga rice cooker berapaan mak?

"Mother...How much is the price of rice cooker, mom?"

Mamake : 1 jutaan yang bagus le...Katanya sedang diskon, harganya jadi 538 ribu

"1 million for good quality... the shop keeper said it was discounted, so the price

be 538 thousand sisa

Pak Inyong: alhamdullilah masih ada

"alhamdullilah, there still money left

(Ep, 10-Gaji Pertama)

In data 8), Pak Inyong's speech accomplishes the maxim's sympathy because he expresses gratitude by saying the word "Alhamdulillah" because he can buy his mother a rice cooker and his salary is still left even though only two thousand rupiah.

The speech function spoken by Pak Inyong is an expressive because Pak Inyong expressing his gratitude by saying the word of "Alhamdulillah".
Feeling reticence maxim gives low value to speaker's feelings. In the principle of politeness, the speaker is forbidden to answer the question how are you with honest answers like in fact my situation is bad. Speakers are required to answer news questions by answering "I'm ok" or hiding the feelings experienced by the speaker. Data 10 displays the speech of Pak Inyong who accomplishes the principle of politeness in feeling reticence maxim. The conversation happened when he introduced himself in front of the class and one of his students asked about the origin of his girlfriend. Pak Inyong quickly diverted the question by starting his lesson.

\section{Murid: Pacarnya orang mana pak?}

"Where's your girlfriend from, sir?"

Pak Inyong: Baiklah...kita langsung mulai saja pelajaran pada pagi hari ini...

\section{"Alright ... let we just start the lesson in this morning ..."}

\author{
Murid-murid: Diajomblo... \\ "He is single..." \\ (Ep.3-Perkenalan)
}

Pak Inyong's speech accomplished feeling reticence maxim because $\mathrm{Mr}$. Inyong did not answer honestly about the situation he felt now even though his students wanted to know if he had a girlfriend or not, but Pak Inyong changed his conversation by starting learning at that time so students could not ask again about the situation felt by the speaker.

The speech function spoken by Pak Inyong is declarative because the speech tells the sentence that decides something, which is to start learning in the sentence "alright...le we just start the lesson".

Maxims from violating the Principles of politeness by Pak Inyong. In episode 1-40 the Inyong Teacher's comics found 71 utterances spoken by Pak Inyong. A total of 16 utterances violated 5 principles of politeness, violation of generosity maxim, violation of approbation maxim, violation of modesty maxim, violation of agreement maxim, violation of feeling reticence maxim. The explanation of which is as follows:

Violations on the maxims of generosity carried out by Pak Inyong's character were found in 2 utterances. Violation of generosity 
maxims occurs when the speaker harms another person intentionally or unintentionally. In data 11 Pak Inyong has violated maxim generosity because it gives a lot of loss to other people. Conversations took place between $\mathrm{Mr}$. Inyong and the students, at that time the students did not accept that Mr. Inyong gave an impromptu test of English with the reason they had not studied yet.

Pak Inyong: Anak-anak hari ini kita ulangan dadakan bahasa Inggris

Children, today we have English test

Murid-murid: Duhh...

Ouch...

Ahh...Jangan pak...Belum belajar pak... Ahh...No sir...Haven't study yet, sir...

Minggu depan saja pak...Jangan sekarang dong...

How about next week sir..Please not now...

\section{(Ep.12-Ulangan Dadakan)}

The utterance spoken by Pak Inyong on data 11) is a violation on generosity maxim. Pak Inyong gave a sudden English test, so the children were not ready to take part in the test. The disadvantage suffered by his students was not being able to answer the question and get a low score because they had not studied for the test.

The speech function spoken by $\mathrm{Mr}$. Inyong is a directive, which is giving orders to his children to take part in a test of English language.

The second violation found in Pak Inyong's speech is a violation on approbation maxim. This violation occurs when the speaker mocks and quips so that it hurts the feelings of others. In the data 12 Pak Inyong quipped his students who hide their cellphones in their lunch boxes. The conversation occurred when Pak Inyong conducted a cellphone raid in $\mathrm{Bu}$ Umi's class.

Pak Inyong: Suka makan hape ya mbak?

Do you like to eat cellphones,sist?

Murid-murid: A hh bapak bisa aja

Uhh... you don't say

(Ep.29-Razia Hape 2)

The violation of aprrobation maxim occurred because Mr. Inyong was annoyed, before he had checked his cellphone and confiscated student's cellphone with Pak
Adman but there were still students who still hide their cellphone, so Pak Inyong insinuated his students. Pak Inyong's innuendo was intentional so that his students understood that they had violated the school rules about being banned from taking cellphones to school.

Pak Inyong's speech on data 12) is an assertive, namely expressing emotions by insinuating others.

The third violation found in Pak Inyong's utterance is a violation of modesty maxim. Modesty maxim violations can occur if the speaker gives a high value for his own quality (boasting). Telling others that you are the best and most superior person or intentionally showing off your own property is a violation of modesty maxim. The dialog on data 13 were violated by Pak Inyong when talking to Kribo in a coffee shop.

Kribo: Jangan-jangan kau ikut sekongkol korupsi dana BOS ya coy? Sadar coy!!Kau ini pendidik! Bukan maling!

"Don't tell me that you joined the BOS funds corruption access? Aware of you! You're an educator! Not a thief!"

Pak Inyong: Sepuluh juta halal kok. Lima ratus empat puluh ribu uang tunai...dan sembilan juta empat ratus enam puluh ribu kebaikan

"Ten million halall. Five hundred and forty thousand cash ... and nine million four hundred and sixty thousands of good karma"

\author{
Kribo: .... \\ (Ep.16-Obrolan Warung)
}

Pak Inyong's speech to Kribo is a violation of modesty maxim because Pak Inyong boasted that he had a high salary and he also said he has good karma because he is a teacher. Pak Inyong's utterance violated modesty maxim because Pak Inyong's utterances gave himself high value by boasting.

The speech function spoken by Pak Inyong is assertive and expressive. The form of assertive speech is acknowledged as indicated by the use of the phrase "ten million clean" and expressive forms of speech that expresses selfarrogance.

The fourth violation found in Pak Inyong's utterance is a violation of agreement maxim. Violations in agreement maxim can occur if the speaker does not have an 
agreement with another person. In a conversation, rejection is a violation of the principle of politeness. Violation of agreement maxim made by Pak Inyong's character to his ex-girlfriend. At that time Pak Inyong's exgirlfriend gave Pak Inyong shoes as birthday present.

Mantan pacar: Selamat ulang tahun mas...Ini buat mamas biar besok jadi guru yang baik

"Happy birthday bro...This is for you for be a good teacher tomorrow"

Pak Inyong: Makasih... Duh... Tapi gimana ntar balesnya... reply?"

"Thank you..ouch..but how can I

Mantan pacar: Lamar saja aku mas!

"Marry me!"

Pak Inyong: Apa lamar!! Kuliah aja belum kelar!!

"What marry!! My college
unfinished!!!

\section{(Ep.32-Sepatu)}

Pak Inyong's utterance violates the agreement maxim because the speaker refused the request of his ex-girlfriend to get married. Pak Inyong indirectly refused the request of his ex-girlfriend by saying that the college was not finished.

Pak Inyong's speech function has an assertive that is complaining to reject the request of his ex-girlfriend who asks to get married.

The last violation found in Pak Inyong's utterance is a violation on opinion reticence maxim. The violation of opinion reticence maxim happen when the participant cannot hide their feelings to the other person. In the principle of politeness telling bad news is considered to violate of politeness. In data 15 , Pak Inyong's utterance violate opinion reticence maxim. The conversation happened when Ki Hajar Dewantara asked about how Pak Inyong felt after becoming a teacher.

Ki Hajar Dewantara: Bagaimana rasanya jadi guru, Pak Inyong? Inyong?"

"How does it feel to be a teacher, Mr.

Pak Inyong: Ya begitulah ada rasa manisnya kadang juga pahit mungkin karena saya masih minim pengalaman.

"Yes that so, there is sweetness, sometimes it's also bitter, maybe because I still lack of experience"

\section{(Ep. 35-Pendidikan)}

Pak Inyong's statement violated the opinion reticence maxim because he answered directly the question of $\mathrm{Ki}$ Hajar Dewantara about his feeling of being a teacher. Pak Inyong's speech above has an assertive speech function, namely expressing his feelings towards hearer.

\section{IV.CONCLUSION}

In accordance with the analysis of the accomplishment of the principle of politeness and violation of politeness maxims spoken in the comic entitled "Pak Guru Inyong" from episodes 1-40, the author concludes that the character can be known through the speech of characters who accomplish the 10 principles of politeness of Leech (2014), which is like helping others, willing to sacrifice and be responsible. In general, Pak Inyong's speech is in accordance with the teacher's instructions in the school who always maintain their behavior and confessed that they are teachers who reflect the virtuous person. This can be seen from the accomplishment of the generosity, agreement, and obliq to $\mathrm{O}$ maxims that prove that Pak Inyong always gives respect to others, likes to help others and respects the efforts of others. From this study it can be concluded that this comic is eligible to bead by children up to adults because it shows utterances that tend to meet the politeness norms that apply in society. Although there are some maxims that are violated by Pak Inyong, the violations occur because they have a positive purpose so that other people respect themselves more and be frank by answering directly the questions of others.

\section{REFERENCES}

Alfia, A. M., Rohmadi, M., \& Purwadi. (2014). Pelanggaran Prinsip Kesantunan dan Implikatur percakapan dalam Acara Pas Mantab di Trans 7. Basastra, 2.

Budiarta, I. W., Ngurah, I. G., \& Rajistha, A. (2018). Politeness In "Adit dan Sopo Jarwo " Animation. Lingua Cultura, 12(February), 25 -30. https://doi.org/10.21512/lc.v12i1.1822

Doko, Y. D. (2017). Kesantunan berbahasa dalam Kumpulan Cerita Rakyat Nusa Tenggara 
Timur. RETORIKA: Jurnal Ilmu Bahasa, 3 (1), 159-169.

Fransischa, L. (2012). Analisis Pelanggaran Prinsip Sopan Santun Dalam Komik Crayon Shinchan Volume 2 Karya Yoshito Usui. Japanology, 1(1), 55-65.

Karim, S. A. (2018). Analysis On Cooperative Principle and Politeness Principle in Guest Complaining at $\mathrm{X}$ Hotel In Kuta-Bali. RETORIKA: Jurnal Ilmu Bahasa, 2(2), 394408. https://doi.org/10.22225/jr.2.2.68.394408

Leech, G. (2014). The Pragmatics of the Politeness. Oxford University Press. https:// doi.org/10.4324/9781315857381

Nurjannah, D. R. (2014). Perlokusi dari Pelanggaran Prinsip Sopan Santun dalam Dorama "Kimi Wa Petto" Episode I Karya Yayoi Ogawa. Japanology, 2(1), 56-66.

Nurlaila, Purwaningsih, E., \& Firmawan, H. (2011). Kesantunan Tindak Tutur Direktif pada Komik Anak Donald Duck dan Terjemahannya dalam Bahasa Indonesia. In Kajian Pragmatik dalam Berbagai Bidang (pp. 454-458). Prasasti II.

Post, E. (1922). Etiquette. New York: Funk and Wagnalls Company.

Qiang, C., \& Kahn, S. M. (2015). Investigation of Visual Language in Malaysia Cartoons: Evidence from Ujang's Comic - Aku Budak Minang. Procedia - Social and Behavioral Sciences, 211, 1252-1260. https:// doi.org/10.1016/j.sbspro.2015.11.166

Sudaryanto. 2015. Metode dan aneka Teknik analisis Bahasa. Yogyakarta: Duta Wacana University. 